Journal of Islamic Medicine

Vol 4(1) (2020), Pages 46-51

e-ISSN: 2550-0074

Original research article

\title{
PENGARUH AKUPUNKTUR JIN'S 3 NEEDLE TERHADAP PENURUNAN INTENSITAS NYERI DIABETIC NEUROPATHY PERIFER
}

\author{
Leny Candra Kurniawan', Ikhwan Abdullah ${ }^{1}$ \\ ${ }^{1}$ Prodi akupunktur Poltekkes RS Soepraoen Malang \\ *Corresponding author \\ Email:leny.candra@ymail.com
}

\begin{tabular}{l}
\hline \\
\hline Keywords: \\
Acupuncture \\
Pain intensity \\
Diabetic Peripheral \\
Neuropathy \\
\hline
\end{tabular}

\section{Abstract}

Diabetic Peripheral Neuropathy is a type of nerve damage that occurs due to diabetes. High blood sugar levels in the long term can cause damage to nerve fibers throughout the body, such as legs, feet, blood circulation, heart, digestive system, and urinary tract. Diabetic Peripheral Neuropathy is a serious complication of diabetes that often causes pain in the limbs. Pain management Diabetic Peripheral Neuropathy is usually by administering pain medication for a long period of time. These medicines will have side effects. The use of acupuncture as an alternative to help reduce the intensity of pain in peripheral diabetic neuropathy has proven to be effective and relatively without side effects. The advantage of acupuncture therapy is that it has relatively no side effects. The general aim of this study is to reduce the intensity of pain in peripheral neuropathy. The research design uses quantitative methods. The study population was all patients with peripheral neuropathy who visited the Harmoni Healthy Clinic in March-May 2019. The sampling method used was accidental sampling. The benefits of this study provide an alternative for DM sufferers to reduce the intensity of neuropathic pain naturally with acupuncture without fear. side effects. From the results of this study it is known that there is an influence of Jin's Three Needle acupuncture in reducing the intensity of pain in Peripheral Neuropathy. Calculations using statistical SPSS 21 with paired sample $t$ test obtained significant results $(0.00)<$ from the value of $\alpha$ (0.05), then $\mathrm{Hl}$ is accepted. So with a significance level of $5 \%$, it can be concluded that Jin's Three Needle acupuncture can reduce the intensity of pain in diabetic peripheral neuropathy. 


\section{LATAR BELAKANG}

Metabolisme karbohidrat, lemak, dan protein. Penyakit ini ditandai dengan meningkatnya kadar gula darah (hiperglikemia) secara cepat dan sangat beresiko terhadap penyakit stroke, jantung, penyakit ginjal, dan kehilangan fungsi syaraf. Gangguan metabolisme glukosa disebabkan oleh kekurangan hormon insulin sehingga glukosa tidak dapat diproses oleh tubuh yang menimbulkan meningkatnya kadar glukosa dalam darah (1)(11).

DM merupakan suatu keadaan di mana kadar gula darah melebihi batas normal. DM juga merupakan faktor risiko terhadap jantung koroner. Bila kadar gula darah naik dan berlangsung lama, maka akan memicu terjadinya arterosklerosis pada arteri koroner. Pasien dengan DM cenderung mengalami gangguan jantung pada usia muda. DM yang tidak terkontrol dengan kadar glukosa yang tinggi cenderung meningkatkan kadar kolesterol total dan trigliserida (2).

Penyakit diabetes dapat menyebabkan beberapa masalah di tubuh terutama apabila tidak menjaga kadar gula darah tetap normal dan membiarkannya tetap tinggi selama bertahun-tahun. Gula darah tinggi dapat merusak saraf yang mengirimkan sinyal dari tangan dan kaki. Kerusakan ini disebut sebagai penyakit neuropati diabetik. Penyakit neuropati diabetik dapat menyebabkan mati rasa atau kesemutan pada jari-jari kaki atau tangan. Gejala lainnya yaitu nyeri seperti terbakar, terkena benda tajam, dan nyeri tumpul. Rasa sakit pada awalnya ringan, tapi nyeri makin bertambah seiring berjalannya waktu dan dapat menyebar sampai kaki atau lengan. Dengan berjalan kaki terasa sangat menyakitkan, bahkan hanya karena sentuhan lembut akan merasakan sakit.(3)

\section{Leny Candra Kurniawan dan Ikhwan Abdullah}

Menurut American Academy of Family Physicians (2016), 10 sampai 20 persen orang dengan diabetes pernah mengalami nyeri saraf. Kerusakan saraf dapat mempengaruhi tidur dan bahkan kualitas hidup secara keseluruhan. Kondisi ini juga dapat menyebabkan penderita diabetes rentan terkena stres (4). Banyak cara yang telah dilakukan oleh penderita untuk mengurangi rasa nyeri akibat Diabetic Neuropathy Perifer. Mulai dari mengkonsumsi obatobatan baik kimiawi maupun herbal, fisioterapi, obat topical penghilang rasa nyeri.(12) Tetapi obat-obatan tersebut terdapat efek samping terutama bila dikonsumsi jangka panjang. Salah satu terapi untuk menghilangkan rasa nyeri akibat diabetes adalah dengan akupunktur. Keuntungan terapi akupunktur adalah relatif tidak mempunyai efek samping. Namun bagi penderita yang takut jarum dan takut nyeri, maka akupunktur kurang diminati walaupun sesungguhnya nyeri pada penusukan akupunktur tidaklah sehebat nyeri jarum suntik (5).

Ada beberapa metode akupunktur yang hanya menggunakan sedikit jarum salah satunya adalah metode Jin's 3 Needle. Diharapkan dengan hanya memberikan terapi pada 3 titik akupunktur penderita tidak merasa takut terhadap banyaknya jarum yang digunakan Jin's 3 Needle adalah metode akupunktur dengan hanya menggunakan 3 titik akupunktur.

Titik yang dipakai untuk terapi Diabetic Neuropathy Perifer adalah:

A. 3 titik kaki (The 3 Leg Points), yang terdiri dari:

1. Zusanli (ST 36)

Lokasi: 3 cun di bawah Dubi (ST 35) pada garis penghubung Dubi dan Jiexi 
(ST 41), 1 jari fibular dari krista tibialis.

\section{Sanyinjiao (SP 6)}

Lokasi: Sisi medial cruris, 3 cun di atas malleolus medialis, tepat di posterior os tibia

\section{Taichong (LR 3)}

Lokasi: pada dorsum kaki, lekuk distal dari pertemuan os metatarsal 1 dan 2 di atas a.dorsalis pedis

B. 3 Titik Tangan (The 3 Arm Points) yang terdiri dari:

1. Quchi (LI 11)

Lokasi: pada lekuk di ujung radial lipat melintang siku

2. Waiguan (TE 5)

Lokasi: 2 cun proksimal lipatan dorsal pergelangan tangan, antara os radius dan ulna

3. Hegu (LI 4)

Lokasi: antara os metacarpal I - II, pertengahan tepi radial os metacarpal II $(6,10)$.

\section{METODE}

Penelitian ini merupakan penelitian kuantitatif pre-experimental dengan pretestpostest design. Populasi penelitian adalah Semua Pasien Diabetic Neuropathy Perifer di Klinik Sehat Harmoni Indonesia pada MaretMei 2019. Sampel yang dipilih untuk penelitian ini adalah Semua Pasien Diabetic Neuropathy Perifer Di Klinik Sehat Harmoni Indonesia pada Maret-Mei 2019 sebanyak 10 orang. Teknik pengambilan sampel menggunakan teknik accidental sampling, yaitu teknik pengambilan sampel dimana sampel kebetulan datang atau dijumpai oleh peneliti pada saat penelitian berlangsung.

Peneliti melakukan pemeriksaan tingkat intensitas nyeri memakai skala nyeri Bourbanis kepada pasien sebelum melakukan Leny Candra Kurniawan dan Ikhwan Abdullah terapi akupunktur. Peneliti melakukan desinfeksi dengan kapas alkohol di area penusukan pada titik akupunktur di daerah tangan atau kaki. Jarum akupunktur dibiarkan tertancap selama 30 menit. Setelah pencabutan jarum, bekas tusukan dideisinfeksi lagi dengan kapas alkohol. Setiap responden dilakukan terapi sebanyak 10 kali, dengan jadwal terapi 3x/ minggu. Pada akhir sesi terapi, peneliti melakukan kembali pengukuran intensitas nyeri.

\section{HASIL PENELITIAN}

Dari penelitian yang dilaksanakan mulai tanggal 1 April sampai dengan 31 Mei 2019 di Klinik Sehat Harmoni Indonesia, dengan jumlah sampel 10 responden, tentang Pengaruh Akupunktur Jin's Three Needle Terhadap Intensitas Nyeri Penderita Diabetic Neuropathy Perifer didapatkan hasil sebagai berikut:

\section{Intensitas Nyeri sebelum terapi Akupunktur}

Tabel 1. Intensitas Nyeri Sebelum Terapi

\begin{tabular}{llll}
\multicolumn{3}{c}{ Akupunktur } & \\
\hline No & Kriteria & Jumlah & Persentase \\
\hline 1 & Tidak Nyeri & 0 & 0 \\
2 & Nyeri Ringan & 0 & 0 \\
3 & Nyeri Sedang & 10 & $100 \%$ \\
4 & Nyeri Berat & 0 & 0 \\
5 & Nyeri Sangat Berat & 0 & 0 \\
\hline
\end{tabular}

Sumber : Lembar Observasi, Maret 2019

Dari Tabel di atas, dapat dilihat bahwa skala nyeri yang dirasakan oleh 10 penderita Diabetic Neuropathy Perifer, semuanya memiliki skala nyeri sedang (100\%).

\section{Intensitas Nyeri sesudah terapi Akupunktur}

Tabel 2. Intensitas Nyeri Sesudah Terapi Akupunktur 


\begin{tabular}{llll}
\hline No & Kriteria & Jumlah & Persentase \\
1 & Tidak Nyeri & 4 & $40 \%$ \\
2 & Nyeri Ringan & 6 & $60 \%$ \\
3 & Nyeri Sedang & 0 & 0 \\
4 & Nyeri Berat & 0 & 0 \\
5 & Nyeri Sangat Berat & 0 & 0 \\
\hline \multicolumn{3}{c}{ Sumber :Lembar Observasi, Maret 2019 }
\end{tabular}

Dari tabel di atas, dapat dilihat bahwa skala nyeri yang dirasakan oleh 10 penderita, semuanya mengalami penurunan, yaitu pada skala tidak nyeri menjadi sebanyak 4 orang $(40 \%)$ dan pada skala nyeri ringan menjadi sebanyak 6 orang (60\%). Sedangkan pada skala nyeri sedang, skala nyeri berat dan skala nyeri sangat berat tidak ada.

\section{Pengaruh pemberian terapi akupuntur Jin's 3 needles terhadap skala nyeri}

Tabel 3. Pengaruh Pemberian Terapi Akupunktur Jin's 3 needles Terhadap Penurunan Skala Nyeri Penderita Diabetic Neuropathy Perifer

\begin{tabular}{lccc}
\hline & \multicolumn{2}{c}{ Intensitas Nyeri } & Penurunan \\
\cline { 1 - 3 } & Pre Tes & Post Tes & Intensitas Nyeri \\
\hline R1 & 5 & 1 & 4 \\
R2 & 4 & 0 & 4 \\
R3 & 4 & 1 & 3 \\
R4 & 6 & 1 & 5 \\
R5 & 5 & 2 & 3 \\
R6 & 5 & 0 & 5 \\
R7 & 5 & 0 & 5 \\
R8 & 6 & 1 & 5 \\
R9 & 5 & 1 & 4 \\
R10 & 5 & 0 & 5 \\
\hline
\end{tabular}

Dari penjelasan tabel 3 dapat disimpulkan bahwa pada sebelum pemberian Terapi Akupunktur Jin's 3 needle, penderita Diabetic Neuropathy Perifer di Klinik Sehat Harmoni Indonesia Malang dengan skala nyeri sedang adalah sebanyak 10 orang (100\%). Sedangkan setelah pemberian Terapi Akupunktur Jin's 3 needle didapatkan hasil

\section{Leny Candra Kurniawan dan Ikhwan Abdullah}

bahwa semua penderita mengalami penurunan intensitas nyeri.

Hasil analisa statistik dengan Uji Paired Sample t-test untuk mengetahui efek akupunktur dalam menurunkan intensitas nyeri Diabetic Neuropathy Perifer di Klinik Sehat Harmoni Indonesia didapatkan tingkat signifikan $\mathrm{p}$ value sebesar $0,00<\alpha(0,05)$ sehingga $\mathrm{H} 1$ diterima yang berarti ada pengaruh pemberian terapi akupunktur untuk menurunkan intensitas nyeri Diabetic Neuropaty Perifer.

\section{PEMBAHASAN}

Berdasarkan hasil penelitian dan analisis data yang diperoleh, menunjukkan bahwa intensitas nyeri yang dirasakan penderita Diabetic Neuropathy Perifer yang dialami oleh 10 responden di Klinik Sehat Harmoni Indonesia Malang sebelum pemberian Terapi Akupunktur Jin's 3 Needle semuanya memiliki intensitas nyeri pada skala nyeri sedang yaitu sebanyak 10 orang (100\%). Sedangkan intensitas nyeri yang dirasakan responden setelah pemberian Terapi Akupunktur Jin's 3 Needle semuanya mengalami penurunan, yaitu pada skala tidak nyeri sebanyak 4 orang (40\%) dan pada skala nyeri ringan sebanyak 6 orang $(60 \%)$. Jika dibandingkan dengan data sebelum terapi akupunktur, semua responden mengalami penurunan intensitas nyeri. Hal ini disebabkan responden mengikuti saran peneliti antara lain melakukan terapi secara teratur, mengatur pola makan, melakukan olah raga rutin, mengurangi berat badan.

Menurut Traditional Chinese Medicine (TCM), akupunktur merupakan suatu cara pengobatan yang memanfaatkan rangsangan pada titik Akupunktur untuk mempengaruhi aliran bioenergi tubuh berdasarkan pada filosofi keseimbangan hubungan antara permukaan tubuh dan organ melalui sistem 
Meridian yang spesifik. Sistem Meridian adalah jalur hubungan antara permukaan tubuh dengan dalam tubuh. Dalam satu Meridian terdapat beberapa titik Akupunktur yang dimanfaatkan sebagai pintu masuk rangsangan ke dalam Meridian (7).

Diabetic Neuropathy Perifer yang berupa rangsangan nyeri di tangan, diterapi menggunakan 3 Titik Tangan (The 3 Arm Points), yaitu quchi (LI 11) berfungsi untuk regulasi Qi dan darah, memperbaiki otot dan persendian; Waiguan (TE 5) berfungsi: mengurangi faktor penyebab penyakit luar dan membersihkan panas; Hegu (LI 4) berfungsi untuk menguatkan Qi, menghilangkan sumbatan di meridian, menyeimbangkan aktivitas Qi ke atas dan ke bawah (Peng, 2000).

Diabetic Neuropathy Perifer yang berupa rangsangan nyeri di kaki, diterapi menggunakan 3 titik kaki (The 3 Leg Points), yaitu zusanli (ST 36) berfungsi untuk memperbaiki lambung dan limpa, menguatkan Qi, darah, serta daya tahan tubuh, dan transformasi phlegm; sanyinjiao (SP 6) berfungsi menggerakkan darah dan mengurangi stasis, menghentikan rasa sakit dan memberi perasaan tenang; LR 3 (Taichong) berfungsi untuk menguatkan limpa dan menyelaraskan lambung, menaikkan Qi lambung dan usus, menguatkan kerja limpa (8).

Menurut Sudirman (9), penusukan pada titik akupunktur akan merangsang proses neural yang dimulai dengan stimulasi saraf diameter kecil yang mengirim implus ke medulla spinalis, mesensefalon, kompleks pituitary-hipotalamus untuk melepas neurotransitter yang menghambat pesan nyeri yang datang berikutnya melalui jalur nyeri lain. Proses melalui matrik jaringan ikat dengan pengiriman signal inflamasi sebagai upaya homeostasis. Setiap stimulasi energi dengan dasar molekuler terjadi "elektro Leny Candra Kurniawan dan Ikhwan Abdullah mechanical model" transduksi energi dan menimbulkan katalisis ensimatik, oksidasi fosforlisasi, transport aktif dan kontraksi otot yang merupakan performans dari sistem transduksi otot yang merupakan performans dari sistem tranduksi energi biologi untuk regulasi pertumbuhan dan perbaikan inflamasi dari matriks ekstraseluler.

Pernyataan tersebut di atas telah didukung dengan analisis data yakni dilakukan Uji Hipotesis menggunakan SPSS statistic 21 dengan paired sample $t$ test didapatkan hasil nilai signifikan $(0.00)<$ dari nilai $\alpha$ (0.05), maka $\mathrm{H} 1$ diterima. Jadi didapatkan kesimpulan ada Pengaruh Akupunktur Jin's Three Needle terhadap penurunan intensitas nyeri pada penderita Diabetic Neuropathy Perifer di Klinik Sehat Harmoni Indonesia.

\section{KESIMPULAN DAN SARAN}

Dari hasil penelitian ini dapat disimpulkan bahwa akupunktur Jin's Three Needle dapat menurunkan intensitas nyeri pada penderita Diabetic Neuropathy Perifer di Klinik Sehat Harmoni Indonesia. Peneliti menyarankan untuk mengembangkan penelitian mengenai akupunktur dengan metode Jin's 3 Needle sebagai terapi untuk menurunkan intensitas nyeri pada penderita Diabetic Neuropathy Perifer.

\section{DAFTAR PUSTAKA}

(1) Adib, M., (2011). Pengetahuan Praktis Ragam Penyakit Mematikan Yang Paling Sering Menyerang Kita. Jogjakarta: Buku Biru

(2) Nurrahmani, U. (2012). Stop Diabetes. Yogyakarta Indonesia : Familia (Group Relasi Inti Media) .

(3) Kohnle, (2008). Symptom Of Diabetic Neuropathy, http://diabetes.niddk.nih.gov/dm/pubs/neu ropathies. Diunduh 30 Maret 2018 
(4) American Academy Family Phisician. (2016). Treating Painful Diabetic Peripheral Neuropathy: An Update. 1 Agustus 2016

(5) Susilo. (2011). Akupunktur Di Rumah Anda . Yogyakarta: Media Pressindo

(6) Jin, R. (2004). Jin' 3-Needle Technique. Shanghai: Shanghai Scientific and Technical Publisher

(7) Saputra, K et al. (2005). Akupunktur Indonesia. Surabaya : Airlangga University Press

(8) Peng, ZF. (2000). Jin Three Needles Therapy (Chinese Edition): Jin San Zhen Liao Fa. Shanghai: Shanghai Science and Technology Literature Publishing House

(9) Sudirman, S. (2009). Akupunktur Untuk Nyeri Dengan Pendekatan Neurosain. Jakarta: Sagung Seto

(10) Zhang, L. (2007). Acupuncture Treatment for Diabetes Mellitus. Beijing China: Shanghai Scientific and Technical Publisher

(11) Suyono S. (2007). Diabetes Melitus di Indonesia.Dalam: Buku Ajar Ilmu Penyakit Dalam. Interna Publishing

(12) Tamsuri, A. (2007). Konsep dan Penatalaksanaan Nyeri. Jakarta : EGC

(13) Idajanti, A. (2012). Patofisiologi Diabetes Mellitus Menurut Teori Kedokteran dan Teori Akupunktur. Surabaya Indonesia : Seminar Penatalaksanaan Diabetes Mellitus Secara Komprehensif.

(14) National Diabetes Information Clearinghouse. (2013). Diagnosis of Diabetes Mellitus. Diakses pada 11 April 2018. 